\title{
Plant product- drug interaction: The case of Blighia sapida stem bark extract and streptomycin or erythromycin is antagonism
}

\author{
Udobi Chinweizu Ejikeme*, Daniel Mbuotidem David \\ Pharmaceutical Microbiology Unit, Department of Pharmaceutics and Pharmaceutical Technology, Faculty of Pharmacy, University of Uyo, \\ Uyo, Nigeria
}

\author{
Email address: \\ ceudobi@yahoo.com (U. C. Ejikeme)
}

\section{To cite this article:}

Udobi Chinweizu Ejikeme, Daniel Mbuotidem David. Plant Product- Drug Interaction: The Case of Blighia sapida Stem Bark Extract and Streptomycin or Erythromycin is Antagonism. American Journal of Life Sciences. Vol. 3, No. 1, 2015, pp. 1-5.

doi: 10.11648/j.ajls.20150301.11

\begin{abstract}
The continuous development of resistance by microorganisms to antibiotics has necessitated the use of combinations of agents for their containment. This has led to the combination of plant products or parts known to have potentials to control microorganisms with antibiotics without any scientific basis by traditional medicine practitioners. Erythromycin and Streptomycin were differently combined with concentrations of Blighia sapida previously known to control Staphylococcus aureus in anticipation of a synergistic or at least additive effect using both the Agar well diffusion method and strip - agar methods. Results obtained showed an undesirable antagonistic effect leading to a complete loss of activity in the case of Erythromycin against Escherichia coli and reduction in activity of streptomycin against both Escherichia coli and Pseudomonas aeruginosa. Plant product-antibiotic combinations in anticipation of synergism should not be done without scientific proof.
\end{abstract}

Keywords: Resistance, Combination, Plant Products, Synergism, Antagonism

\section{Introduction}

Infections caused by most microorganisms often fail to respond to standard treatment leading to prolonged illness and greater risk of death. The difficulty in treating these bacterial infections emanates from the fact that most of the organisms have developed resistance to a wide range of drugs. They are therefore, able to exhibit resistance to a wide range of antibacterial agents through different known mechanisms. The efflux pump system found in some organisms for instance, extrudes antibiotics from cells making sure that the concentration of antibiotics required to inhibit or destroy such cells is not attained. Efflux pump inhibitors are however known to prevent the action of these pumps resulting in increased intracellular concentration of antibiotics and therefore, its ability to inhibit or destroy the organism. Plants have been reported to be a source of such inhibitors. Scientists have established that crude extracts of some plants and pure compounds from such plants can potentiate the activity of antibiotics in-vitro [1] [2] e.g Epichatechin gallate from Camellia sinensis has been reported to potentiate
Norfloxacin [3].

The resistance of microorganisms to antibiotics generally, has led to increased interest in plant products amongst scientists for possible use in the control of antibiotic resistance because they have been found to have significant healing powers and can be used safely without the side effects of drugs [4],[5]. They owe these powers to the presence of certain compounds especially secondary metabolites found in plants e.g alkaloids, saponins, tannins, cardiac glycosides etc [6].

The co-administration of these plant products with known antibiotics especially those fast loosing relevance due to development of resistance has therefore been suggested. These combinations are known to be useful in decreasing the degree of resistance of most bacteria to the antibiotics, reverse the acquired resistance and generally help in the reduction of the emergence of resistant strain. Blighia sapida is a tropical evergreen tree that belongs to the sapindaceae family [7]. It is a native of West Africa though also cultivated in tropical America. It is well distributed in Nigeria though found more commonly in the forest of the savannah region 
[(8]. In the West coast of Africa, this plant has found so much use among the traditional medicine practitioners for the treatment of a wide range of ailments, e.g extract from the leaves is used in the treatment of conjuctivities [9]. Traditionally, so many diseases have been treated with Blighia sapida. They include fever, malaria, dysentery, burns dental decay, constipation etc. The roots, bark, leaves, capsules and seeds were identified in the treatment of 22 diseases in Benin [10]

This paper presents the results of an effort to combine the methanolic extract of the stem bark of Bighia sapida a well known plant of high medicinal value whose parts have been extensively used in the West coast region of Africa for the treatment of various ailments and Streptomycin an aminoglycoside, and then Erythromycin a macrolide, for an improved activity against Escherichia coli and Pseudomonas aeruginosa (both Gram negative organisms not very easy to control) through a yet to be determined mechanism of action.

\section{Materials and Methods}

\subsection{Test Organisms}

The organisms used (Escherichia coli ATCC 25722 and Pseudomonas aeruginosa and Staphylococcus aureus) were obtained from the stock of organisms in the Pharmaceutical Microbiology laboratory, Faculty of Pharmacy, University of Uyo, Uyo, Nigeria.

\subsection{Drugs}

All the antibiotics used (Streptomycin and Erythromycin) were obtained from standard pharmacy shops in Uyo, Nigeria.

\subsection{Collection of Plant Materials}

Fresh stem bark of Blighia sapida were collected from Ikot Ide village, Nto Edino clan in Obot Akara local Government Area of Akwa Ibom State, Nigeria. The plant was identified and authenticated by $\mathrm{Dr}$ (Mrs) Margaret Bassey of the Department of Botany and Ecological studies, University of Uyo and the specimen voucher number UUH $67 \mathrm{G}$ was assigned to it.

\subsection{Treatment of Sample}

Fresh stem bark of Blighia sapida was thoroughly washed with clean water and chopped into small pieces. These were dried at room temperature for seven days to reduce moisture and to ease pounding. The dried samples were pulverised using mortar and pestles into a powdered form.

\subsection{Extraction}

$500 \mathrm{~g}$ of the pulverised stem bark was cold macerated with $70 \%$ ethanol for 72 hours at room temperature with agitation three times a day to enhance extraction. The extract was filtered out using No 1 Whatman filter paper. The filtrate was evaporated to dryness using a rotary evaporator. The concentrated extract was then stored in airtight containers until required.

\subsection{Phytochemical Screening}

The ethanolic extract obtained was screened for the presence of secondary metabolic constituents using the standard methods of Trease and Evans [11] [12].

\subsection{Susceptibility Test}

The agar plate diffusion method was used. $0.5 \mathrm{ml}$ of an overnight culture of the test organism was transferred aseptically into a Petri dish. $20 \mathrm{ml}$ of molten nutrient agar was aseptically dispensed into the Petri dish, mixed thoroughly with the culture and allowed to solidify. A sterile cork borer with a diameter of $4 \mathrm{~mm}$ was used to bore holes in the solid agar. Varying concentrations of extract, antibiotics or their combinations were aseptically introduced into the holes and the plates were incubated at $37^{\circ} \mathrm{C}$ for 24 hours after which the zones of inhibition were measured accordingly.

\subsection{Determination of Minimum Inhibitory Concentration (MIC) and Minimum Bactericidal Concentration $(\mathrm{MBC})$}

The MIC of both the antibiotics and the plant extract were determined using the tube dilution method [13]. Two- fold serial dilution of the extract and antibiotics was carried out aseptically to give varying concentrations ranging from $100 \mathrm{mg} / \mathrm{ml}-6.25 \mathrm{mg} / \mathrm{ml}$ for the extract and 0.0625 $0.001953125 \mathrm{mg} / \mathrm{ml}$ for the antibiotics. Each of the dilutions was inoculated with $0.1 \mathrm{ml}$ of the inoculum and the tubes were incubated at $37^{\circ} \mathrm{C}$ for 24 hours .Microbial growth observed as turbidity in tubes was looked out for and lowest concentration that showed no growth was considered the MIC. The concentrations which inhibited growth were further plated out on sterile nutrient agar in plates and incubated at $37^{\circ} \mathrm{C}$ for 24 hours. The lowest concentration that showed no growth was considered the minimum bactericidal concentration.

\subsection{Combination Studies}

\subsubsection{Agar Well diffusion}

The agar well diffusion and the strip agar diffusion methods were used. $0.1 \mathrm{ml}$ of an overnight suspension of the test organism was aseptically transferred to a sterile Petri dish, $20 \mathrm{ml}$ of molten nutrient agar was aseptically dispensed into the Petri dish, properly mixed and then allowed to solidify. A sterile cork borer with $4 \mathrm{~mm}$ diameter was used to bore holes through the agar and $100 \mathrm{mg} / \mathrm{ml}$ of the extract plus different concentrations of the test antibiotics were introduced into the bored holes. The plates were incubated at $37^{\circ} \mathrm{C}$ for 24 hours. The diameters of the zones of inhibition were noted.

\subsubsection{Strip-Agar Diffusion}

Strips of adsorbent paper were saturated with solutions containing different concentrations of test antibiotic and the working extract. The strips were placed on the surface of the agar plates already seeded with the test bacteria such that the 
strips touch each other at ninety degrees. The plates were then incubated at $37^{\circ} \mathrm{C}$ for 24 hours.

\section{Results}

Table 1. Showing Phytochemical constituents of the ethanolic extract of Blighia sapida.

\begin{tabular}{llc}
\hline S/NO & Constituent & \\
\hline 1 & Alkaloid & + \\
2 & Cardiac glycoside & + \\
3 & Saponins & + \\
4 & Tannins & + \\
5 & Flavonoids & + \\
\hline
\end{tabular}

\subsection{Susceptibility Tests}

The stem bark extract did not have any antibacterial effect on both the Escherichia coli and Pseudomonas aeruginosa but gave a zone of inhibition of $25.00 \mathrm{~mm}$ at $200 \mathrm{mg} / \mathrm{ml}$ and $14.00 \mathrm{~mm}$ at $100 \mathrm{mg} / \mathrm{ml}$ against Staphylococcus aureus (a Gram positive bacteria)

\subsection{Minimum Inhibitory Concentration and Maximum Bactericidal Concentration}

Results of the MIC and MBC of Erythromycin and Streptomycin against Staphylococcus aureus - an organism to which both the test antibiotics (Erythromycin and Streptomycin) and the extract of Blighia sapida are susceptible are shown in table 2.

Table 2. Showing MIC and MBC values of Erythromycin and Streptomycin against Staphylococcus aureus

\begin{tabular}{lll}
\hline Concentration $\mathbf{~ M g / m l}$ & Erythromycin & Streptomycin \\
\hline 0.0625 & - & - \\
0.01325 & $-* *$ & - \\
0.015625 & $-*$ & - \\
0.0078125 & + & $-* *$ \\
0.00390625 & + & $-*$ \\
0.001953125 & + & - \\
\hline
\end{tabular}

$+=$ Turbid (Growth)

- = Not Turbid (No Growth)

* = MIC Value

$* *=\mathrm{MBC}$ Value

\subsection{Combination Studies}

Results obtained when $100 \mathrm{mg}$ of the extract of Blighia sapida and different concentrations of Erythromycin and Streptomycin were used to challenge the Gram negative test organisms to see if there will be improved activity instead showed a reduction in inhibition zones (Table 3 and 4). This is further confirmed to be an antagonistic action from the results of the strip agar diffusion test (Figure 1).

Table 3. Showing zones of inhibition ( $\mathrm{mm}$ ) of Streptomycin and Erythromycin against the test organisms (Escherichia coli and Pseudomonas aeruginosa)

\begin{tabular}{|c|c|c|c|c|c|}
\hline Erythromycin & & & Streptomycin & & \multirow{3}{*}{$\begin{array}{l}\text { Ps.aeruginosa } \\
(\mathrm{mm})\end{array}$} \\
\hline \multirow{2}{*}{ Concn (Mg/ml) } & E. coli & Ps.aeruginosa & \multirow{2}{*}{ Concn $(\mathrm{Mg} / \mathrm{ml}$} & E. coli & \\
\hline & $(\mathbf{m m})$ & $(\mathbf{m m})$ & & $(\mathbf{m m})$ & \\
\hline 1 & 22.00 & NI & 1 & 29.00 & 25.00 \\
\hline 0.5 & 18.00 & NI & 0.5 & 21.00 & 5.00 \\
\hline 0.25 & 17.00 & NI & 0.25 & 20.00 & 2.00 \\
\hline 0.125 & 15.00 & NI & 0.125 & 19.00 & 0.00 \\
\hline
\end{tabular}

Key: NI=No Inhibition

Table 4. Showing zones of inhibition ( $\mathrm{mm}$ ) of Streptomycin and Erythromycin and their combinations with100mg/ml of the stem bark of Blighia sapida against the test organisms (Escherichia coli and Pseudomonas aeruginosa)

\begin{tabular}{|c|c|c|c|c|c|}
\hline \multicolumn{3}{|l|}{ Erythromycin } & \multicolumn{3}{|l|}{ Streptomycin } \\
\hline Concn & E. coli & Ps.aeruginosa & Concn & E. coli & Ps.aeruginosa \\
\hline $100 \mathrm{mg} / \mathrm{ml}$ of extract + & $(\mathbf{m m})$ & $(\mathbf{m m})$ & $100 \mathrm{mg} / \mathrm{ml}$ of extract + & $(\mathbf{m m})$ & $(\mathbf{m m})$ \\
\hline $1.0 \mathrm{mg} / \mathrm{ml}$ & NI & NI & $1.0 \mathrm{mg} / \mathrm{ml}$ & 22.00 & 19.00 \\
\hline $0.5 \mathrm{mg} / \mathrm{ml}$ & NI & $\mathrm{NI}$ & $0.5 \mathrm{mg} / \mathrm{ml}$ & 18.00 & 9.00 \\
\hline $0.25 \mathrm{mg} / \mathrm{ml}$ & NI & NI & $0.25 \mathrm{mg} / \mathrm{ml}$ & 13.00 & NI \\
\hline $0.125 \mathrm{mg} / \mathrm{ml}$ & $\mathrm{NI}$ & $\mathrm{NI}$ & $0.125 \mathrm{mg} / \mathrm{ml}$ & 11.00 & NI \\
\hline
\end{tabular}

Key: NI=No Inhibition

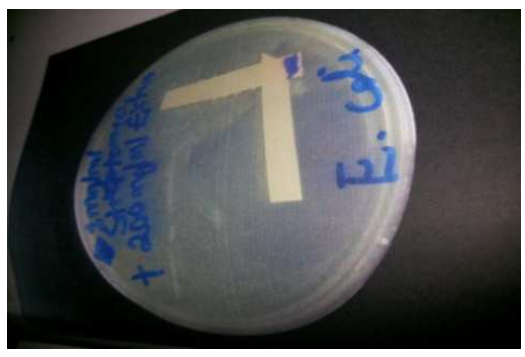

Fig. 1. Effect of the combination of $1 \mathrm{mg} / \mathrm{ml}$ of streptomycin with 200mg/ml of the stem bark of Blighia sapida against E.coli showing antagonistic response

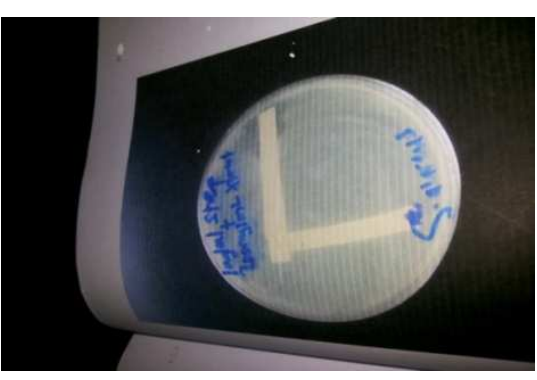

Fig. 2. Effect of the combination of $1 \mathrm{mg} / \mathrm{ml}$ of streptomycin with $200 \mathrm{mg} / \mathrm{ml}$ of the stem bark of Blighia sapida against Staphylococcus aureus showing antagonistic response. 


\section{Discussion}

The use of combinations of antibiotics in the treatment of infections is a common trend lately due to the frequency of resistance especially among the Gram negative organisms. Drug combinations are used so that the synergistic and additive potentials of each of the combinants can be exploited. They are also used to improve efficacy and further retard the development of resistance to the combinants by microorganisms. The use of these combinations however, can only be justified if they produce a synergistic or at least an additive effect against the invasive organisms. The clinical use of antibiotic combinations has been widely criticized because it is believed to be wasteful and associated with high incidence of adverse reactions as well as encouraging the general misuse of antibacterial agents but generally, the more pronounced problem of dual compound therapy remains the difficulty in matching the pharmacokinetics of two different molecules.

Scientists have also discovered that the crude extracts of some plants and some pure compounds from such plants can potentiate the activities of antibiotics in-vitro [1] [2] e.g, Epichatechin gallate from Camellia sinensis is known to potentiate Norfoxacin [3] while epigallocatechin gallate has been reported to potentiate lactams [14]. Plants have also been reported to be a source of efflux pump inhibitors that decrease the effectiveness of efflux pumps by blocking their activity thereby allowing the accumulation of antibiotics inside the bacterial cell so that they can get access to their target sites.

The combination of plant extracts and antibiotics especially first line antibiotics which are no longer in use because of the development of resistance has therefore been encouraged in some places. In some cases the expected synergistic results may not be achieved as was the case in this study.

Results obtained showed that while Erythromycin had no inhibitory effect on Pseudomonas one of the Gram negative test organisms, streptomycin was able to inhibit the growth of both E. coli and Pseudomonas aeruginosa (Table 3). This is further confirmed by the results of the MIC and MBC, (Table 2) which shows that streptomycin is not only bacteriostatic to the organisms but also bactriocidal. The Blighia sapida extract however, could only inhibit the Gram positive Staphylococcus aureus at very high concentration of $100 \mathrm{mg} / \mathrm{ml}$ as has been previously reported by [15]. Table 4 shows results of the use of the combination of the test agents at concentrations where they had previously had some effect on the organisms and $100 \mathrm{mg} / \mathrm{ml}$ of Blighia sapida (a concentration that had previously shown activity against Staphylococcus aureus). Results confirm a complete loss of activity in the case of Erythromycin and reduction in activity in Streptomycin. This result which means that the combinats are antagonising one another is confirmed by the strip agar results shown in fig. 1 which is the result pattern obtained in cases of antagonism.

In certain parts of the world, the concomitant use of plant products and antibiotics for quick and effective action is known. It is always believed that their combination will always bring about an improved or synergistic action. While this can be true considering some reported cases. Results from this work shows that some combinations may be dangerous even when the combinats have shown some activity individually.

\section{Conclusion}

The administration of plant extracts and orthodox medicines without scientific confirmation of their synergistic or additive effect should not be encouraged.

\section{References}

[1] Marquez, B. (2005): Bacterial efflux systems and efflux pump inhibitors. Biochimie. 87(12): 1137-1147.

[2] Smith, E. C. J., Williamson, E. M., Wareham, N., Kaatz, G. N, Gibbons, S. (2007) Antibacterials and modulators of bacterial resistance from the immature cones of chamacyparis lawsoniana. Phytochem. 68(2) 210-217.

[3] Gibbons, S. (2004). Anti-Staphylococcal plant natural products. Nat. Prod. Rep. 21: 263-277

[4] Steve B. (2004). Herbal Property Dictionary. Lifelong Press

[5] Udobi, Chinweizu Ejikeme. (2008). Antibacterial activities and phytochemical analysis of the Leaf, Stem bark and root of the African Locust Bean (Parkia biglobosa) (Jacq) Benth (Mimosaceae). PhD. Dissertation. Ahmadu Bello University, Zaria.

[6] Lewis, K. Ausubel, F. M. (2006). Prospects for plant derived antibacterials. Nat. Biotechnol. 24(12): 1504-1507.

[7] Nwozo S. O, Iwuoha E. I., Waryo T and Kgarebe B (2014). Isolation, Partial purification and characterization of antifungal trypsin inhibitor protease from the seed of Blighia sapida K. D Koenig (Ackee). Afri. Journ. Biotech. 13 (29) 2996-3007.

[8] Esuoso KO, Odetoun SM. Proximate chemical composition and possibleindustrial utilization of $B$. sapida seed and oils. Journal of Phytotherapy Research 2005; 72(7):311-313.

[9] John-Dewole, O. O. and Popoola, O. O. (2013). Chemical, Phytochemical and Antimicrobial Screening of Extracts of $B$. sapida for Agricultural and Medicinal Relevance. Nature and science, vol. 11(I10) 12-17

[10] Veronica M. Dossou, Jacob K. Agbenorhevi, Sussana combey, Sarah Afi-Koryoe (2014). Ackee (Bilghia sapida) fruit arils: Nutritional, phytochemicals and antioxidant properties. Int. Journ. Nut. Food Sci. 3 (6) 534-537

[11] Trease, E. G and Evans, W.C. (2006). Pharmacognosy $15^{\text {th }}$ Ed. Elsevier Limited. 3-5

[12] Sofowora, A. (1982). Medicinal plants and Traditional Medicine in Africa. John Wiley and sons Ltd. N. Y. 97 - 105, $142-146$.

[13] Baron, J. E., \& Fingold, S. M. (1990). Methods for testing antimicrobial effectiveness. In: Bailey Scotts Diagnostic Microbiology. Mosby, C. V. (ed.) Missouri. 171- 194. 
[14] Zhao,W.H., Hu, Z.O. Okubo, S, Hara, Y., shimanura, T. (2001) Mechanism of synergy between Epigallocatechin gallate and lactams against methicillin resistant staphylococcus aureus. Antimicrobial. Agents chemother. 45(6): 1737 - 1742
[15] Ubulom, P. M; Udobi, C. E; Akpabio, E. I; Eshiet, U. (2013). Antimicrobial activities of Leaf and Stem bark extracts of Blighia sapida Journal of Plant Studies; 2 ( 2) 47-52 